\title{
Memories Not Yet Formed: Commemorating the Franco-Prussian War and the Paris Commune
}

\section{Karine Varley}

Reporting on the unveiling of a monument dedicated to the defence of Paris during the Franco-Prussian War, L'Intransigeant asserted that memories of the siege had disappeared into oblivion. The capital's 'heroic history, epic resistance' should, the newspaper argued, have meant that 'no memory should be so indestructible, none should be so piously preserved.' In reality, however, 'none has disappeared so quickly; none has been so abandoned', to be replaced by mere banalities (Talmeyr, 1883). The reason for such forgetting was, L'Intransigeant suggested, self-evident: it was impossible to remember the Franco-Prussian War without evoking memories of the Paris Commune.

The events of 1870-71 were among the most painful in France's recent past. After defeat in the Franco-Prussian War, it was reduced to having to accept the annexation of AlsaceLorraine, indemnities of five billion francs and a humiliating march through the streets of Paris by victorious German forces. Protesting their opposition to the government's decision to surrender as a betrayal by bourgeois factions, monarchists and the war-weary countryside, on 18 March 1871 National Guardsmen and the revolutionary left rose up to proclaim a Paris Commune. In the ensuing civil war, the army that had been hastily assembled by the government in Versailles killed thousands of Parisians in the semaine sanglante (week of blood) of 21-28 May 1871. Yet whereas those who died in the siege of Paris in the FrancoPrussian War would be remembered in unprecedented numbers of monuments, commemorations, works of art and literature (Varley, 2008), the 1870s saw no memorials erected to the Communard dead, their memories being largely ignored or vilified in cultural representations. Only when moderate republicans gained control of the government and 
passed a full amnesty on 11 July 1880 were memories of the Commune rehabilitated and former Communards reintegrated into the Republic (Joughin, 1955: 455-57).

The claims made by L'Intransigeant stand in direct opposition to the arguments advanced in much of the scholarship on the experiences of 1870 to 1871 in Paris. Historians have suggested that after the government crushed the Commune in May 1871, it buried memories of the slaughter of Parisians by the Army of Versailles in silence. Thus Bertrand Tillier argues that images of the Commune were censored as part of a concerted effort of forgetting by the early Third Republic. The Commune was condemned to 'inexistence' as a 'nonevent' and even a 'non-lieu de mémoire' $(2004: 18,28)$. Echoing Tillier, Colette Wilson suggests that the conservative governments of the 1870s engaged in 'active forgetting' and that the period 'was one of unmitigated political, social, cultural repression and censorship' (2007: 12, 8).

This article presents an alternative approach, however. By exploring how the Paris Commune served to shape memories of the Franco-Prussian War, it challenges suggestions of forgetting. Whereas much of the scholarship treats memories of the Paris Commune in isolation from memories of the Franco-Prussian War, this article suggests that the two episodes were tightly connected. The swift succession of events meant that memories of the Franco-Prussian War became overlaid with memories of the Commune. Moreover, far from memories of the violence of the semaine sanglante having been suppressed, this article suggests that their absence was because they had not yet been formed.

\section{Remembering and forgetting}


The violent demise of the Paris Commune has led historians to reason that its absence from public memories in the 1870 s cannot simply have been the consequence of passive forgetting. However, the repression of memory presupposes the existence of that memory in the first place. Cognitive psychologists argue that experiences usually leave memory traces in individuals which are recorded in the episodic memory system. Particularly dramatic or unique experiences or those with an emotional impact leave more dense memory traces (Winter and Sivan, 1999: 12). Yet scholars from a variety of disciplines have argued that public or collective memories do not occur naturally but have to be created. Constructing lieux de mémoire or sites of memory becomes necessary, Pierre Nora argues, because modern societies move inexorably towards a state of forgetting (1996: 21). Groups create collective memories to define their identities and to assert political, cultural or social legitimacy (Fentress and Wickham, 1992; Confino, 1997; Fritzsche, 2001). As one of the pioneers in developing concepts of collective memory, Maurice Halbwachs draws upon the work of Emile Durkheim to argue that individual memories are socially embedded, deriving meaning from the groups to which they belong (1992: 52-53). When it comes to the construction of public recollections of war, however, if historians such as Jay Winter and Emmanuel Sivan have chosen to refer to 'collective remembrance', rather than 'collective memory', it is because they conceptualize it as a combination of social narratives (1999: 610). To them, the homogeneity implied by notions of a 'collective memory' is unsatisfactory and deeply problematic when dealing with traumatic and divisive experiences.

The many traces left by the turmoil of the Franco-Prussian War and the Paris Commune made their memories difficult to escape and even more difficult to quash. It therefore seems counterintuitive to suggest that they could have been forgotten, especially in the period that 
followed immediately thereafter. Indeed, according to Freud, once experienced, the past is permanently lodged in the mind. Individuals do not really forget, but rather bury memories deep within their unconscious minds (White, 1975: 445). It may therefore be more conducive to conceive not so much of the destruction of memory but of its displacement. Paul Ricoeur takes this analysis a stage further, suggesting that forgetting needs also to be understood in terms of depth. Memories that are out of reach may be 'powerless', 'unconscious', 'virtual', or located somewhere in a kind of infinite 'abyss', and therefore effectively equivalent to forgetting (Ricoeur, 2004: 414-40). This raises two intriguing possibilities. The first is that forgetting may be reversed, even if memories are not easily accessible. The second is that having moved difficult memories to the unconscious sphere, one might forget that one has forgotten. However, these concepts assume that problematic memories can easily be transferred to a place where they are out of reach and less harmful, whereas it is precisely the most painful memories that are often the most difficult to escape (Ankersmit, 2001: 300-05). Moreover, the notion of displacement assumes a certain passage of time.

Influenced by the field of neurology, forgetting has often been treated merely as a 'malfunction' of memory. Yet memory and forgetting are closely entwined, with the latter not necessarily being merely the enemy of the former. Whether forgetting is active or passive, there remains significant debate about whether it is a sign of discomfort or even illness, or whether it is a function of a healthy memory. Psychoanalysts have regarded some types of forgetting as being caused by the 'repressive erasure' of an uncomfortable memory, signalling discomfort and desired avoidance (Connerton, 2008: 60). It may be connected with trauma-induced neurosis marked by dissociation or amnesia (Ankersmit, 2001: 309). Yet forgetting might also be regarded as enabling the organization and orientation of 
memory. Thus Nietzsche suggests that 'the role of [...] active oblivion is that of a concierge: to shut temporarily the doors and windows of consciousness'. It should be welcomed as a form of power, he argues, because without it, there would be no space for the present, 'no happiness, no serenity, no hope, no pride' (1956: 189). Without some kind of forgetting, communities and indeed nations risk being forever locked in turmoil or stasis. In this sense, forgetting may not be diametrically opposed to remembering; the relationship might perhaps more fruitfully be understood as a kind of 'negotiation' (Ricoeur, 2004: 413).

Yet if forgetting might be an involuntary and inherent aspect of modern societies, it may also be active. Because the construction of memory is selective and functional, it often militates against accommodating alternative ideas (Fentress and Wickham, 1992: 134). Where societies choose not to recall aspects of the past, not remembering may appear at once active in terms of a deliberate avoidance and passive in terms of a lack of memory. It might therefore be useful to consider the absences in public memory not as indications of forgetting but as silences. To this end, Jay Winter has analysed silence as the space beyond words or the omissions from what is discussed (2010: 4). Maintaining silence involves social groups having to define what is appropriate and upholding what they consider may be said and what may not. Eviatar Zerubavel has developed this argument to suggest that collective forgetting might be reconceived as conspiracies of silence. Thus something that is widely known may be purposely ignored, and something that is remembered by an individual may be absent from public discourse. These silences may resemble open secrets and may in turn be surrounded by a 'meta-silence', in which the silence itself is never discussed (Zerubavel, 2010: 32, 39). 
The problem remains, however, that the Franco-Prussian War and the Paris Commune were neither forgotten nor the subjects of silence. Even the more troubling aspects such as the violence perpetrated by the Army of Versailles were either purposely played out or involuntarily revived in the years that followed. The issue was rather one of the creation and layering of memories. The suppression of the Commune and the political climate of the 1870s significantly constrained opportunities publicly to remember what had happened. Yet in seeking to commemorate the Franco-Prussian War, it was impossible to wind the clock back to create a memory that was not in some way shaped by the Commune. The FrancoPrussian War and the Paris Commune were at once connected, the latter being in part caused by the consequences of the former, and distinct in their causes, meanings and significance. Not only were memories constructed and expressed through many of the same locations and actors, but they concerned events that happened within a relatively compressed period of time. The rapid shift from the Franco-Prussian War ending in January 1871 to the rise of the Paris Commune two months later meant that before memories of the former had been established, they had already been altered by the influence of the latter. The layering of memories did not end with the Commune's demise. Efforts to commemorate the first siege of Paris from October 1871 meant that memories of the Franco-Prussian War came in turn to overlay those of the Commune. Yet while the process may have served to impede direct or immediate recall, being in some respects comparable to what psychologists conceive of as retroactive or proactive interference (Winter and Sivan, 1999: 12), it did not fully obscure memories of the Commune. Following Eelco Runia's (2006) suggestion that forgetting does not occur when the past remains tied to the present, far from being consigned to oblivion, the Paris Commune endured as a subject of vivid political, social and cultural contestation in the capital. The example of how the Franco-Prussian War and the Paris Commune were remembered therefore has wider implications for scholars, demonstrating the need to look 
beyond notions of forgetting and silence towards the processes by which memories are formed.

\section{The Army of Versailles}

The layering of memories of the Franco-Prussian War and the Paris Commune first manifested itself in the military parade of 100,000 men at Longchamp on 29 June 1871 . The capital had not seen such a review since 6 June 1867, when Napoleon III had sat alongside Tsar Alexander II and King Wilhelm of Prussia in the full splendour of the International Exposition. This time, however, the army marched for four hours before President Adolphe Thiers, watched by crowds of around 9000 people, including foreign diplomats and 300 deputies from the National Assembly. Newspapers hailed the event as an uplifting boost for France and as nothing less than the beginning of the national recovery after the defeat by Germany. The moderate republican Le Temps described it as the 'renaissance' of France (1 July 1871), the conservative Le Figaro noted that the country had rediscovered its army (D’Auney, 1871a), while the conservative Le Petit Journal impulsively announced a return to good fortunes (1 July 1871). Coming less than two months after the French government had signed peace terms with Germany, the parade seemed to strike a markedly different tone to the realities of the disasters that had just befallen the country, its army and Paris. But as the government and those witnessing the parade were acutely aware, the army on display was not that which had fought the Franco-Prussian War but that which had fought against the Paris Commune. The parade replicated the order of battle of 20 May 1871, being led by Marshal MacMahon as Commander-in-Chief of the Army of Versailles, followed by the first army corps led by General Ladmirault, General Vinoy leading the army reserve, the fourth 
corps of General Douay, the fifth army corps of General Clinchant, the second corps of General de Cissey, the cavalry brigade of General de Galliffet and the third cavalry corps of General du Barail (D’Auney, 1871a). In other words, memories of the army's defeat in the Franco-Prussian War had been superseded by memories of its victory over the Paris Commune.

That did not, however, mean that the humiliation by Germany had been forgotten or that the army's success in the civil war had become a redemptive sacrifice beneath which memories of its violence against the Commune could be buried. Indeed, newspapers reported that Thiers and MacMahon did not bask in triumphalism but were overcome with emotion (The Times, 3 July 1871; Le Gaulois, 1 July 1871). The awkward silences during the ceremony told of discomfort and the fear of reopening fresh wounds. Moreover, whereas in 1867, soldiers had been encouraged to shout 'Long live the Emperor!' to Napoleon III who was dressed in full ceremonial uniform, this time, they were under orders to remain silent as they passed Thiers in sombre civilian attire (Truesdell, 1997: 143). The political sensitivities of the occasion were such that no military bands were permitted, while the Marseillaise was strictly off limits because it had been the anthem of the Paris Commune (Le Gaulois, 1 July 1871). The awkward anti-Commune tone of the event was also evident in the uncomfortable silence that greeted one deputy's shouts of 'Long live the Republic' (The Times, 3 July 1871). According to Le Figaro, onlookers reacted with stupor; interpreting republicanism as being synonymous with support for the Commune, they regarded such expressions as little short of seditious (D’Auney, 1871a).

In the summer that followed, the monarchist-dominated National Assembly sought to seize control over memories of the Paris Commune in its enquiry into the republican Government 
of National Defence's handling of the Franco-Prussian War. While it reserved the strongest condemnation for the National Guard which had gone on to lead the Communard uprising in March 1871, it claimed that the army's discipline in the Franco-Prussian War had collapsed under the damaging influence of 'revolutionary party ideas' (Assemblée Nationale, 1873: 428-29). The National Assembly enquiry into the rise of the Paris Commune also cast doubt upon the reliability of the country's armed forces in the Franco-Prussian War. The Marquis de la Rochethulon reported that whereas soldiers in the provinces had been inexperienced but patriotic, elements of the mobile National Guard could not be relied upon to fight against the Germans during the first siege of Paris (Assemblée Nationale, 1872: 387-90). By contrast, the enquiry heaped praise on the Army of Versailles for restoring social order in the capital and defeating the Commune (Assemblée Nationale, 1872: 2). Far from seeing the semaine sanglante in terms of arbitrary violence against men, women and even children, the National Assembly and the government viewed the army's actions as having been necessary for the quelling of 'criminal' disorder (Tombs, 1994: 89). As a consequence, it did not dispute the army's actions or the manner with which it had conducted itself.

\section{Commemorating the first siege of Paris}

That the government neither could nor wanted somehow to peel back memories of the Commune to reveal untainted memories of the Franco-Prussian War became abundantly clear in the siege of Paris commemorations in the years that followed. Not only had many of the men who had fought in the Franco-Prussian War gone on to be incorporated into the Army of Versailles, but many of their commanders had as well. From 4 April 1871, the first corps of the Army of Versailles was led by General Ladmirault who had commanded the 
fourth corps of Napoleon III's Imperial Army in the Franco-Prussian War; the second corps was under General de Cissey who had led the second division of the Army of the Rhine in August 1870; the third, meanwhile, was under General du Barail, who had led the cavalry at Mars-la-Tour in August 1870. The three corps were supplemented by two divisions of repatriated prisoners of war under General Douay, who had commanded the seventh corps of the Imperial Army, and General Clinchant, who had led the Army of the East. Having led the thirteenth corps of the reserve forces of the Imperial Army in the Franco-Prussian War, General Vinoy took overall command of the Army of Versailles. Like many of his fellow officers, however, Vinoy's actions in the civil war came to overshadow his record in the Franco-Prussian War. Indeed, it was his order to shoot the Communard Emile Duval on 2 April 1871 that marked the beginning of the killing of hostages by Versailles forces (Horne, 1965: 311). Others who had fought in the Franco-Prussian War would later also be indelibly associated with memories of the civil war. Despite having commanded forces at Champigny in December 1870, General Susbielle became known to Parisians for having led the seizure of the cannon at Montmartre on 18 March 1871. General Bocher, who had led his men into the Buzenval sortie of 19 January 1871, meanwhile, would be remembered as having been involved in the capture of the Issy fortress from Communard forces on 12 May.

The commemorations marking the battles around Paris during the Franco-Prussian War thus became sites of contestation for memories of the Commune as well. In addition to having been fought by many of the same officers and soldiers, the temporal and physical connection between the two events was such that many of the locations that had witnessed combat during the Franco-Prussian War were also the sites of hostility in the civil war. Thus Rueil was the scene of fighting against German forces on 19 January 1871 and between Versailles and Communard forces on 3 April. Saint-Cloud, meanwhile, witnessed combat in mid- 
January 1871 and in mid-May. Montretout saw clashes with German troops in January 1871 and between Versailles and Communard forces on 14 May. The commemorations to mark the battles of the Franco-Prussian War could not be hermetically sealed from memories of what followed. Nor did the organizers seek to do so. Indeed, the early Franco-Prussian War commemorations around Paris saw the fault-lines of l'année terrible played out in the open, with monarchist and Bonapartist memories challenging republican ones and Catholic memories opposing Communard ones.

The first commemorations at Le Bourget took place just five months after the semaine sanglante as the arrest of former Communards continued and as the debris was still being cleared away. The battle had started with General de Bellemare launching a surprise attack against Prussian forces stationed at Le Bourget on 28 October 1870. News of French defeat two days later, however, brought shockwaves to the capital, fuelling left-wing attacks against the republican Government of National Defence's handling of the war. Press reports do not give any sense of the social makeup of those who attended the first commemorations, but an image in the conservative Le Monde illustré indicates that there were many workers among their number (4 November 1871). The reports of the crowd's responses to the speeches suggest that significant proportions identified as republicans as well. Their social background and political views were therefore typical of the supporters of the Commune. General de Bellemare used the occasion to justify his actions and to blame the defeat on the government. In so doing, however, he was met with hostility from the crowd (Dalsème, 1871: 140; Grimm, 1871). When he declared 'Long live France', they responded 'Long live the Republic', and began surging forward until police stepped in to protect him (De Praissac, 1871). It was above all the speech by the Bonapartist writer Francis Aubert that sparked the greatest controversy, however. Directly accusing many of the men who had fought at Le 
Bourget of being driven by selfish political motivations, Aubert contrasted the heroism of those who braved death to do their duty with those who thought only of the 'lure of gain' (Dichart, 1871: 41; Duquet, 1893: 330-31). Recalling the uprising in Paris the day after Le Bourget as a foretaste of the later insurrection, Aubert blamed France's collapse on the agents of civil war who 'tried to profit from the presence of the enemy to foment sedition' (Aubert, 1871: 11). Once again, the crowds expressed their opposition with frequent interruptions of 'Long live the Republic' (O’Squarr, 1871).

The first commemorations for the battle of Champigny in early December 1871 were also marked by the intrusion of memories of the Paris Commune. There, however, the political makeup of the crowds was different to those at Le Bourget. In April 1871, Champigny had rallied to the Versailles government, and although special trains from Vincennes allowed 2030,000 people to attend, they were predominantly conservative (Dangelle, 1871; Le Gaulois, 4 December 1871). Indeed, Le Monde illustré depicted the crowds appearing wealthier than those at Le Bourget a few weeks earlier (9 December 1871). Thus although General Ducrot, who had led the long-awaited sortie to the left bank of the Marne, found himself confronted by noisy and 'agitated' crowds, they were mostly supportive of his message (Dangelle, 1871; Le Gaulois, 4 December 1871). Despite not having served in the Army of Versailles, Ducrot attacked the supporters of the Commune as 'barbarians' who had 'neither a nation nor a family' and who had thrust the country into 'patricide' and civil war (Ducrot, 1871: 14). Unlike in Le Bourget, the crowds responded with spontaneous cries of 'Long live France'; a lone dissenting voice shouted 'Long live the Republic' but did not succeed in provoking any hostile response (D’Aunay, 1871b; Le Gaulois, 4 December 1871). 
The Buzenval sortie of 19 January 1871 was even more overtly connected with memories of the Paris Commune. Two days after the battle had ended in failure, a small but violent uprising broke out in Paris. On the verge of civil war, and with rapidly diminishing supplies of food, the government finally resolved to open negotiations for an armistice with the Germans. In the public mind, the sortie was associated with suspicions that General Trochu had sent large numbers of National Guards into battle to 'bleed' the force of some of its radical elements (Horne, 1965: 234). Significant proportions of the units involved in the offensive were recruited from the $5^{\text {th }}, 6^{\text {th }}, 7^{\text {th }}, 10^{\text {th }}$ and $14^{\text {th }}$ arrondissements of Paris which went on to register strong support for revolutionary leaders in the elections to the Commune on 26 March 1871 (Dolivet, 1872: 21-22; Tombs, 1999: 25, 110). Trochu, however, rejected the allegations, countering that many of the losses were due to a lack of discipline within the National Guard (Rousset, 1912: 367-89).

The first anniversary commemorations of Buzenval were attended by many prominent military figures who had not only served in the Franco-Prussian War but who had gone on to serve in the Army of Versailles as well. At Saint-Cloud, the guests of honour included Generals Trochu, Ducrot, Vinoy and Douay. They were accompanied by General Faron, who had led his men in the assault against Communard forces at Issy on 25 April 1871, and General Vergé, who had commanded an assault on Paris on 21 May (Tombs, 1981: 131). While Saint-Cloud and Rueil had supported the Versailles government in 1871(Jellinek, 1971: 183), many of those attending the commemorations were former National Guardsmen from Paris. Against mutterings of disagreement, the bishop of Versailles therefore did not merely pay tribute to the dead of Buzenval but used the occasion to launch a blistering attack against the men who had already 'begun preparing the horrors of the Commune' (Le Siècle, 21 January 1872; Le Figaro, 21 January 1872). Meanwhile, at the ceremony in nearby Rueil, 
National Assembly deputy Amédée Langlois made what reporters claimed was a 'conciliatory' speech (Le Petit Journal, 1872a; Paris-Journal, 1872a). A veteran of Buzenval but perhaps more significantly the Versailles government's intermediary to the Parisian National Guards on 18 March, Langlois was, however, interrupted several times by rival cries of 'Long live the Republic!' and 'Long live France!' from the crowds. Fearing the incident might escalate into violence, the mayor of Rueil intervened with the diplomatic solution that 'France and the Republic are one; but, gentlemen, it is France before everything' (Le Figaro, 21 January 1872).

In ceremonies across the Parisian banlieue, such clashes were characteristic of how memories of the Commune were being expressed through commemorations for the FrancoPrussian War. Far from commemorations being sites of consensus around the Republic (Dalisson, 2013: 66), they were occasions of bitter contestation. Although the country was governed as a republic and although not all republicans had supported the Paris Commune, many Communards had identified primarily as republicans (Tombs, 1999: 116-17). Many had, moreover, seen the government's surrender to Germany as a reactionary betrayal of the republican ideal of the nation in arms, fighting to the bitter end (Balathier-Bragelonne, 1872: 290; Forrest, 2009: 125-27). In the struggle against the monarchist-dominated government of Versailles that followed, Communards feared that like its predecessors, the new Republic risked being crushed by the conservatism of the provinces. In this context, expressing support for the Republic was widely interpreted as signalling support for the ideas that had driven the Paris Commune, rather than any more moderate vision of republicanism. By the same token, many anti-Communards, especially monarchists, Bonapartists and Catholics, virulently opposed any suggestion that the state should be conceived in republican terms or that loyalty to the Republic should take precedence over loyalty to France. Having never 
accepted the legitimacy of the uprising of 4 September 1870 that had brought the collapse of the Second Empire, they continued to fight in the Franco-Prussian War despite, rather than because, the country had become a republic.

That the early Franco-Prussian War commemorations around Paris did not descend into further hostility between the rival political camps was due in significant part to police and government intervention. Such was the case at Saint-Denis in January 1872. After the Commune had effectively waged war against the Catholic Church, the left-wing municipal council opposed the Red Cross's decision to organize the Franco-Prussian War commemorations as a religious service. It therefore resolved to seize control of the ceremony and transform it into an event at which members of the clergy would be banned (Archives Nationales, 1871b). On learning of the scheme, the prefect of police addressed an urgent letter to Interior Minister Auguste Casimir-Perier warning that not only were the municipal council's commemorations being planned as an attack against the Catholic Church, but that the ceremony would be attended by large numbers of workers as well. The prefect of police cautioned that local politicians intended to make 'inflammatory and offensive speeches' echoing the Commune's opposition to the government's decision to end the war with Germany in January 1871 (Archives Nationales, 1872). With workers threatening to spark disorder and to turn the event into a reprise of the Commune, the interior minister agreed to cancel the commemorations.

\section{Commemorating the Paris Commune}


In contrast with the annual ceremonies to remember the Franco-Prussian War, the civil war did not give rise to any regular commemorations during the 1870 s. In part, this was simply due to the consequences of the suppression and the purge. The reality was that most of the Commune's leaders were imprisoned or in exile during this period, while many of its supporters had perished in the violence of May 1871. Between 1871 and 1878, specially convened military tribunals tried over 46,000 suspected Communards; 13,450 were found guilty, including 3313 condemned in absentia (Shafer, 2005: 100). The purge also saw 4586 Communards being deported to New Caledonia in March 1872. Hundreds more fled abroad, including several prominent former leaders of the Commune. Membership of the International was made a criminal offence in August 1871, while those convicted of having participated in the Paris Commune were forbidden from taking political office. Quite simply, there was scarcely anyone left to organize any kind of remembrance for the victims of the suppression.

The commemorations that did take place in the early 1870s were for the Army of Versailles and the victims of Communard violence. In the weeks immediately following the semaine sanglante, the centre-right deputy for Seine-Inférieur, Roger-Léon Anisson-Duperron, proposed holding a service for all the officers and soldiers who had died for the 'deliverance of Paris and the re-establishment of law and order' (Archives Nationales, 1871). However, the proposal was withdrawn on 22 June 1871 for reasons which are not disclosed in the archival records. A year later, a small number of memorial services were held for the soldiers who had died in the conflict and for those killed by the Communards. On 28 May 1872, a funerary service for the Volontaires de la Seine was held at Asnières, attended by many of the families of the dead (Le Petit Journal, 1872c; Gérard, 1872). A similar service was held at Sainte-Clothilde basilica for the officers of the Army of Versailles who had died 
in combat against the Commune (Paris-Journal, 1872b). More numerous were the services for the civilian victims of the Commune. One of the most significant was held at St JeanBaptiste church in Belleville for the fifty hostages shot by the Commune on rue Haxo on 26 May 1871. Attended by the prefect of the Seine, along with General Ladmirault and officers of the republican guard, it attracted large crowds of sympathizers from the local community (Le Petit Journal, 1872b; D'Aunay, 1872). Similar services for the victims of the Commune were held at La Madelaine, Notre Dame and in Arcueil (Paris-Journal, 1872b).

Despite the deaths of Versailles forces providing politically useful opportunities for conservatives to shift attention to the violence perpetrated by the Commune, the memorial services were never intended to become annual events. In part, this may be due to the relatively small losses suffered by the Army of Versailles. Official figures gave a total of 877 dead, comprising 83 officers and 794 soldiers, with a further 183 missing (MacMahon, 1872: 44; Tombs, 2012: 681). It may also be due to the fact that unlike those killed in the Franco-Prussian War, most of the dead soldiers were not assigned any dedicated graves. Many were simply buried along with the Communards, with no thought of treating them differently (Hennebert, 1871; Séguin, 1879; Tombs, 2012: 691). While Generals Lecomte and Thomas were given their own memorial at the Père Lachaise cemetery, it was as victims of the uprising of $18 \mathrm{March}$, rather than as combatants. ${ }^{1}$ Moreover, the granting of a permanent grave for forty republican guards in the Belleville cemetery in 1876 was due to their being killed as hostages in the rue Haxo massacre, not because they had fought for the Army of Versailles (Conseil municipal de Paris, 1914: 24-27).

\footnotetext{
${ }^{1}$ General Lecomte and General Thomas, the Commander-in-Chief of the National Guard during the FrancoPrussian War, were captured and executed by anti-government crowds at Montmartre on 18 March 1871.
} 
Yet when comparing how the two experiences of 1870-1871 were remembered in Paris, what was remarkable was not the absence of commemorations for the civil war but rather the proliferation of commemorations for the Franco-Prussian War. The annual ceremonies and construction of memorials dedicated to the Franco-Prussian War were unprecedented and owed as much to pressure from the Germans as to any demand on the French side. The German authors of the 1871 Treaty of Frankfurt included the duty to maintain soldiers' graves in the peace terms. These obligations resulted in the French government launching a five-year programme to provide permanent graves for over 87,000 soldiers at a cost of more than two million francs (Archives Nationales, 1873; Anon, 1879: 477). No previous European conflict had seen this kind of provision for the dead and it was not until the outbreak of the First World War that such a programme would be repeated. The failure to dedicate spaces to the civil war dead or to remember them in annual ceremonies or memorials in the 1870 s was therefore merely a reflection of conventional practices.

A further explanation for the absence of civil war commemorations lies in the twin issues of the construction and evolution of memories. In contrast with those historians who argue that memories of the Commune's violent demise were repressed, Robert Tombs has questioned whether the Commune's demise really was so violent. Disputing notions of the Versailles soldiers as fanatical reactionaries who engaged in arbitrary killings, Tombs suggests that many were reluctant to fire on Parisians and that most acted in an orderly, rational manner (1986: 796). Having analysed cemetery records, along with a variety of other sources, Tombs also challenges the claims that between 20,000 and 40,000 people were killed by Versailles forces during the semaine sanglante. Instead, he proposes a figure of between 5700 and 7400 . For Tombs, therefore, 'it is the creation of myth, not the suppression of memory, that is the issue' $(2012: 693,700)$. While this research has opened important new 
avenues of enquiry in relation to the scale and nature of the violence, it is far from uncontested. Indeed, disputing the findings, John Merriman maintains that the semaine sanglante was 'the biggest massacre in Europe of the nineteenth century'. Pointing the finger firmly at the Army of Versailles, he argues that 'Thiers's army gunned down thousands of ordinary men, women, and occasionally, children' (2014: 2). Whether or not the figures proposed by Tombs are any closer to the true scale of the losses lies outside the scope of this article. However, his suggestion that the relative absence of memories of the Commune's violent suppression was because they had not yet developed can be supported by an analysis of Communard remembrance during the 1870s and in the years that followed.

For socialists, neo-Jacobins and republican supporters of the Paris Commune, the victory of the Versailles government in May 1871 represented a devastating blow to their aspirations for social, economic and political upheaval. As was the case after the crushing of the June Days uprising in 1848, in the period that followed, former Communards turned to reflect upon the consequences of the suppression for the prospects of a workers' revolution. Rather than focusing upon the Communard dead as victims or martyrs, they sought to perpetuate the ideas that had driven them (Nicholls, 2019: 45). Indeed, even while the fighting was ongoing, the Commune had resolved to commemorate those who died in its defence by naming rooms in buildings dedicated to social works (D'Arsac, 1871: 32). Initial acts of remembrance therefore centred upon the uprising of 18 March 1871, rather than the semaine sanglante. Through the 1870 s, from their places of exile in cities such as London and Geneva, former Communards gathered to commemorate 18 March and the ideals it represented (Le Gaulois, 1873; D’Auney, 1874). Even when the partial amnesty for former Communards enabled their return to France in early 1880, the uprising of 18 March 
remained the focus for commemorations, being marked by a banquet attended by four hundred guests (Montancey, 1880; La Fare, 1880).

The shift towards remembering the suppression of the Commune began largely as a chance development. It emerged from desires to honour the memory of the socialist Gustave Flourens, who had been killed by Versailles forces and buried at the Père Lachaise cemetery in April 1871. Benefiting from the new freedoms afforded to them by the partial amnesty and spurred on by the prospects of a full amnesty for former Communards, on Sunday 4 April 1880 around two thousand socialists met to place a wreath at his grave (Rebérioux, 1984: 620). Just a few weeks later, socialist groups passed a formal resolution to hold a mass demonstration at Père Lachaise on 23 May in memory of those who had died for the 'social emancipation' of the proletariat (Joughin, 1955: 400; Tartakowsky, 1999: 62). With mounting speculation that socialists planned to represent the Communard dead as 'martyrs' of the Army of Versailles and fearing a political backlash from moderate republicans and conservatives, Interior Minister Ernest Constans ordered police to intervene (Le Petit Journal, 30 May 1880). In the end, only around 500 people attended the gathering, but the overreaction by the government and the press transformed what might have been a relatively small-scale meeting into an occasion of political significance (Le Siècle, 23, 24 May 1880; Le Petit Journal, 25 May 1880; Le Temps, 26 May 1880).

The heavy-handed government response played into socialist narratives of the Third Republic as a bourgeois oppressor, helping to ensure that the gathering at Père Lachaise would become an annual event. Claims that the suppression of the Commune represented an assault upon the proletariat were articulated almost immediately afterwards by Karl Marx in London, but it was the writings of the Communard Benoît Malon in 1871 and the 
Communard sympathizer Prosper-Olivier Lissagaray in 1876 that had the greatest domestic impact (Shafer, 2005: 112). The French revolutionary tradition had long held an ambiguous relationship with the bourgeoisie. Yet despite the experiences of 1848 and the attempts by Marx to situate the 1871 uprising within a broader paradigm of class conflict, it was not until the late 1870 s that growing numbers of French socialists came to view the Republic as a bourgeois enemy bent on asserting its dominance (Marx, 1871). In so doing, they began to regard the suppression of the Commune as part of a wider counterrevolutionary betrayal, placing the events of 1871 into a model that connected it with the revolutions of 1789,1830 and 1848. By viewing the Third Republic through the prism of class oppression, socialists rendered the Commune not an episode of the recent past but a cause of present and ongoing political and social conflict.

In subsequent years, the gatherings at Père Lachaise attracted increasing numbers and became more organized. As a site of resistance against the Versailles forces and the location of a mass grave for the victims, the mur des féderés (Communards' wall) became a lieu de mémoire for the left. According to Le Gaulois, between two and three hundred people attended in 1881; the following year, the same newspaper reported a gathering of between seven and eight hundred, while L'Intransigeant put the figure at 4000 (Le Gaulois, 1881; Lambert, 1882; L'Intransigeant, 1882). Police, meanwhile, estimated that five hundred had attended in 1881, rising to 2000 in 1884 (Tartakowsky, 1999: 66). Speakers began to evoke what they claimed was socialists' duty to remember the victims, vowing revenge against the likes of General de Galliffet, whom they saw as the architects of the repression (L'Intransigeant, 1882, 1883a; Le Gaulois, 1883). Blanquists in particular placed an increasing emphasis upon attending such gatherings in the 1880 s, practicing 'not a politics of revolution, but a politics of anniversary remembrance' (Hutton, 1981: 120). Thus far from 
laying 'the tombstone of forgetting on the crimes and the last vestiges of the Commune', as Gambetta had claimed (Joughin, 1955: 457), the amnesty served to unleash and transform memories, turning attentions away from the violence perpetrated by Communards to the crimes committed by the Army of Versailles.

\section{The monument to the defence of Paris}

In the construction of a monument to the defence of Paris, the enduring influence of memories of the Commune upon memories of the Franco-Prussian War was inescapable. On 12 February 1878, the General Council of the Seine voted to commemorate the 'last struggle of Parisians' in the Buzenval sortie of January 1871 (Archives Nationales, 1878). The monument, after which the business district La Défense would later be named, soon transformed into a wider symbol for the siege of Paris. But through its location, orientation and imagery, it conveyed a complex and ambiguous set of memories (Archives de Paris, 1879b). The council's resolution to place the monument on the pedestal that had previously been occupied by a statue of Napoleon at the Courbevoie roundabout was, on the face of it, a practical and cost-effective decision. The location also benefited from being directly aligned with the Arc de Triomphe and the Champs-Elysées across the Neuilly bridge (Dorsch, 2010: 113). Yet despite the president of the council claiming that it was where National Guardsmen had assembled on the eve of battle in January 1871 (L'Intransigeant, 1883b), it was not a site that resonated in public memories and rarely featured in any contemporary accounts. It was, however, widely known as the scene of a skirmish between Versailles and Communard forces on 2 to 3 April 1871. The choice of location therefore seemed designed 
to evoke not just the defence of Paris against the Germans but the defence of Paris against Versailles.

Just as the Paris municipal council opted for a relatively conservative vision of Marianne in its concurrent competition for a statue representing the Republic, so the General Council of the Seine was careful to avoid any overtly provocative imagery for its monument. That did not mean stifling potentially contentious imagery altogether, however. The rules of the competition to design the statue stated that it must comprise two figures, the first representing Paris and the second being one of its defenders (Thomas, 1879: 2; Grimm, 1879; Le Figaro, 1879). Beyond that, however, there were few stipulations. Indeed, after around a third of the over one hundred proposed statues ignored the rules, the jury decided to waive the restrictions (Archives de Paris, 1878, 1879a; Archives Nationales, 1879). Significantly, sculptors were free to pay homage to the National Guard, despite its association with the Paris Commune. The winning entry by the noted sculptor Ernest Barrias did precisely that, comprising a female figure of Paris wearing the greatcoat of a National Guardsman, holding a flag in one hand and a sword in the other. In choosing to portray the city in such a manner, Barrias defied conservative attacks on the reputation of the National Guard to suggest a patriotic legitimacy in its later actions under the Commune. At Paris's feet, a wounded Garde Mobile loaded up his rifle, ready to fight to the last bullet. Behind them, Barrias placed a woman sobbing at the loss of her sons, symbolizing the sacrifices made by Parisians.

In conveying an image of Parisian defiance despite the suffering, Barrias affirmed republican and socialist narratives of the city being compelled to surrender by the government against its will that had been at the heart of the Communard uprising. Many of 
the other entrants to the competition emphasized the city's patriotic resistance as well (Havard, 1879). None, however, went as far as Auguste Rodin, whose proposed statue comprised a female allegory of Paris screaming with fury. One of Paris's wings was broken, yet she still dominated the warrior who clutched a sword that was plunged into the ground. The anger expressed in the statue seemed to convey conflicting emotions: a call to revenge, or the powerlessness of the defeated (Milner, 2000: 203). Taking his artistic cues from François Rude's Le départ des volontaires en 1792 and from Michelangelo's Pietà, Rodin misjudged the political climate, underestimating the extent to which observers continued to remember the Franco-Prussian War through the prism of the Paris Commune (Le Gaulois, 1879). In crowning Paris with a Phrygian cap, which had been banned after the Commune, Rodin evoked not just the spirit of the capital's revolutionary heritage but the strident patriotism of its recent past. Reflecting upon his failure to make it through to the second round of the competition, Rodin later conceded that his statue 'must have seemed too violent, too vibrant' for the political environment of the time (Coquiot, 1917: 107).

At the unveiling ceremony in August 1883, the right and left-wing press were united in their insistence that the monument which was supposed to commemorate the defence of Paris in the Franco-Prussian War also served to conjure up memories of the Commune. Senior members of the government declined their invitations, fearing what might happen at the ceremony (Gazette de France, 13 August 1883). Only Interior Minister René WaldeckRousseau attended, but to minimize potential controversy, everyone except the president of the General Council of the Seine, Barthélemy Forest, was forbidden from speaking ( $\mathrm{La}$ Justice, 13 August 1883). To symbolize the unity of the Republic, patriotic societies, freemasons and trades unions were invited to march past the monument following a parade by the army. As they filed past Waldeck-Rousseau and the prefect of police, however, 
several workers shouted 'Long live the amnesty!', prompting the two men to leave accompanied by cries of 'Long live the social revolution!' (L'Intransigeant, 1883b). Despite the passage of the amnesty having officially reconciled the two elements of l'année terrible, the sudden overt intrusion of memories of the Commune into the commemoration of the Franco-Prussian War was both unwelcome and uncomfortable for moderate republicans as well as conservatives. Newspapers of all political shades denounced the monument and the ceremony for reviving difficult memories. The centrist Gil Blas criticized the tone of occasion as 'infantile and puerile' (14 August 1883). The conservative Le Gaulois took offence at the statue itself, claiming that in symbolizing the Republic and National Guard, it represented, 'Incapacity and Indiscipline' (13 August 1883). The monarchist Gazette de France deplored how it returned thoughts to the 'criminals' of 1870-71, glorifying 'the demagogy of the Blanquist faction, of those who were responsible for 31 October, 19 January, and 18 March' (14 August 1883). The pro-Communard L'Intransigeant, meanwhile, claimed the ceremony bore the echoes of the semaine sanglante, the army's hostile demeanour standing as testimony to its lingering 'rancour' towards the Republic (14 August 1883). In this, as in many other cases across the capital, honouring the sacrifices of the Franco-Prussian War did not serve to 'consolidate the regime' (Dalisson, 2013: 59), but to highlight its contested character.

The French government also sought to restrict speeches at the ceremony because it feared that growing revanchist sentiment might cause 'international complications' (Archives de Paris, 1883). Yet while support for a war of revenge against Germany had been steadily growing among moderate republicans in the 1870 s and early 1880 s, the nationalism that drove such sentiments was inseparably tied with the nationalism that had driven the Paris Commune. Indeed, the connection was perhaps most vividly manifested in the transition of 
Henri Rochefort from Communard in 1871 to revanchard by the late 1880 s. The revanchisme of the republican centre and the revanchisme of the socialist left sat in awkward juxtaposition at the inauguration of the monument to the defence of Paris. It did not, however, make the Commune any more palatable to even the most ardent revanchards such as the nationalist poet Paul Déroulède, who had been a soldier in the Army of Versailles during the civil war (Joly, 1998: 30). Twelve years on from the Franco-Prussian War and the Commune, the monument to the defence of Paris showed that it remained impossible to remember the former without evoking memories of the latter.

\section{Conclusion}

The Franco-Prussian War and the Commune represented distinct experiences in the history of Paris, but their close temporal proximity, as well as their shared spaces and protagonists, rendered them inseparable in public memories. Thus as Parisians sought to commemorate the Franco-Prussian War, they found themselves also remembering the Commune. The siege by German forces was so rapidly succeeded by a second siege during the civil war that memories of the Franco-Prussian War had not had time to form before they were overtaken by the experiences of the Commune.

The notion that memories of the Paris Commune were stifled as part of a conspiracy of silence has become as much a part of the narrative of l'année terrible as the semaine sanglante itself. Yet the shift in how the Commune was remembered, from focusing upon the ideas that inspired it in the 1870 s to focusing upon its violent suppression in the period that followed, highlights the need for historians to exercise caution when dealing with 
lacunae in memory or the appearance of forgetting. One of the main problems in analysing forgetting is that while memories may be explicit or implicit, visible or latent, forgetting often takes no tangible form. It is more than simply an absence, as it presupposes a memory that was once there but is no longer. Yet absence may not necessarily denote deliberate or incidental forgetting, or indeed 'focused, directed and purposeful silence' (Winter, 2010: 4). Rather than a memory existing in 'latent' form but requiring activation (Ricoeur, 2004: 433), it may be that that memory never existed or that it had not yet been created. Such was the case with the events of 1870-1871. Just as memories of the Franco-Prussian War had not been formed before being overtaken by the Commune, so historians struggle to find memories of the semaine sanglante in the 1870 s because they had not been formed yet either. 


\section{References}

Archives de Paris, 1878. VR161. Minutes of the General Council of the Seine, 30

November 1878.

Archives de Paris, 1879a. VR 161. Minutes of the General Council of the Seine, 29 April 1879.

Archives de Paris, 1879b. VR 161. Minutes of First Session of Jury, 29 November 1879.

Archives de Paris. 1883. VR 161. Minutes of Inauguration Commission, 28 July 1883.

Archives Nationales, 1871a. C2817. Proposal by Anisson-Duperron.

Archives Nationales, 1871b. F1cI 171. Deliberations of the Municipal Council of Saint-

Denis 23 December 1871.

Archives Nationales, 1872. F1cI 171. Prefect of police to Interior Minister, 6 January 1872.

Archives Nationales, 1873. C2817. Commission to examine the proposed law on

conserving the graves of soldiers killed in the last war. Sessions of 20, 24 January 1873.

Archives Nationales, 1878. F1cI 172. Minutes of the General Council of the Seine, 12

February 1878.

Archives Nationales, 1879. F1cI 172. Letter from Prefect of the Seine, 9 January 1879.

Ankersmit, F. R. 2001. The Sublime Dissociation of the Past: Or How to Be(come) What

One is no Longer. History and Theory, 40(3), 297-99.

Anon. 1879. Recueil des traités, conventions, lois, décrets et autres actes relatifs à la paix avec l'Allemagne. Paris: Imprimerie Nationale.

Assemblée Nationale. 1872. Enquête parlementaire sur l'insurrection du 18 mars 1871.

Vol. 1. Versailles: Cerf.

Assemblée Nationale. 1873. Enquête parlementaire sur les actes du gouvernement de la défense nationale. Rapport, Vol. 3. Paris: Cerf et Fils. 
Aubert, F. 1871. Discours prononcé le 30 octobre 1871 au Bourget par M. Francis Aubert en l'honneur des militaires tués au Bourget dans les combats des 28, 29 et 30 octobre 1870. Paris: Imprimerie Charles Noblet.

Balathier-Bragelonne, A. 1872. Paris insurgé. Histoire illustrée des événements accomplis du 18 mars au 28 mai 1871. Paris: Le Voleur.

Confino, A. 1997. Collective Memory and Cultural History: Problem of Method. American Historical Review, 102 (5), 1386-1403.

Connerton, P. 2008. Seven Types of Forgetting. Memory Studies, 1(1), 59-71.

Conseil municipal de Paris. 1914. Année 1913. Rapports et documents deuxième partie.

Paris: Imprimerie Nationale.

Coquiot, G. 1917. Rodin à l'hôtel de Biron et à Meudon. Paris: Librairie Ollendorff.

Dalisson, R. 2013. Les guerres \& la mémoire. Enjeux identitaires et célébrations de guerre en France de 1870 à nos jours. Paris: CNRS Editions.

Dalsème, A. J. 1871. Paris pendant le siège et les soixante-cinq jours de la Commune. Paris: E. Dentu.

Dangelle, G. 1871. Le 2 décembre. Le Petit Journal, 4 December 1871.

D’Aunay, A. 1871a. La revue d'hier. Le Figaro, 1 July 1871.

D’Aunay, A. 1871b. L'anniversaire de Champigny. Le Figaro, 4 December 1871.

D’Aunay, A. 1872. L'anniversaire du massacre des otages. Le Figaro, 30 May 1872.

D’Auney, A. 1874. L’anniversaire du 18 mars. Le Figaro, 21 March 1874.

D’Arsac, J. 1871. La guerre civile et la Commune de Paris en 1871. Paris: F. Curot.

De Praissac, G. 1871. La cérémonie du Bourget. Le Gaulois, 1 November 1871.

Dichard, H. 1871. Une page de l'histoire du siège de Paris par les Prussiens. La première affaire du Bourget (30 octobre 1870). Paris: Mauger, Capart et Cie. 
Dolivet, C. 1872. Histoire de la Garde Nationale et des bataillons mobilisés du IXe arrondissement avant et pendant le siège de la capitale année 1870-71. Paris: Chez l'auteur.

Dorsch, M. 2010. French Sculpture Following the Franco-Prussian War, 1870-1880:

Realist Allegories and the Commemoration of Defeat. Farnham: Ashgate.

Ducrot, A-A. 1871. Discours du General Ducrot à la cérémonie anniversaire de la bataille de Champigny. Paris: E. Dentu.

Duquet, A. 1893. Guerre de 1870-1871. Paris La Malmaison, Le Bourget, et le trente et un octobre 21 octobre-1 novembre. Paris: G. Charpentier et E. Fasquelle.

Fentress, J. \& Wickham, C. 1992. Social Memory. Oxford: Blackwell.

Forrest, A. 2009. The Legacy of the French Revolutionary Wars. Cambridge: Cambridge University Press.

Fritzsche, P. 2001. The Case of Modern Memory. Journal of Modern History, 73(1), 87117.

Gazette de France, 13 August 1883.

Gazette de France, 14 August 1883.

Gérard, M. 1872. Service du bout de l'an. Le Gaulois, 31 May 1872.

Gil Blas, 14 August 1883.

Grimm, T. 1871. Chronique. Le Petit Journal, 1 November 1871.

Grimm, T. 1879. Le monument de la défense de Paris. Le Petit Journal, 27 November 1879.

Halbwachs, M. 1992. On Collective Memory. Chicago: University of Chicago.

Havard, H. 1879. Le monument de la défense de Paris. Le Gaulois, 26 November 1879.

Hennebert, E. 1871. Guerre des communaux de Paris: 18 mars-28 mai 1871 par un officier supérieur de l'armée de Versailles. Paris: Librairie de Firmin Didot frères. 
Horne, A. 1965. The Fall of Paris: The Siege and the Commune 1870-1. London: Macmillan. Hutton, P. H. 1981. The Cult of Revolutionary Tradition: The Blanquists in French Politics, 1864-1893. Berkeley: University of California Press.

Jellinek, F. 1971. The Paris Commune of 1871. London: Victor Gollancz.

Joly, B. 1998. Déroulède. L'inventeur du nationalisme. Paris: Perrin.

Joughin, J. T. 1955. The Paris Commune in French Politics, 1871-1880: The History of the Amnesty of 1880. New York: Russell \& Russell.

La Fare, A. 1880. Le 18 mars. Le Gaulois, 18 March 1880.

Lambert, L. 1882. La Manifestation Blanqui. Le Gaulois, 29 May 1882.

La Justice, 13 August 1883.

Le Figaro, 21 January 1872.

Le Figaro. 1879. Au Luxembourg. Le Figaro, 30 April 1879.

Le Gaulois, 1 July 1871.

Le Gaulois, 13 August 1883.

Le Gaulois. 1871. La cérémonie de Champigny. Le Gaulois, 4 December 1871.

Le Gaulois. 1873. L’anniversaire du 18 mars à Genève. Le Gaulois, 20 March 1873.

Le Gaulois. 1879. Le monument allégorique de la défense de Paris. Le Gaulois, 25

November 1879.

Le Gaulois. 1881. Manifestation au Père Lachaise. Le Gaulois, 30 May 1881.

Le Gaulois. 1883. Le 28 mai. Le Gaulois, 28 May 1883.

L'Intransigeant. 1882. Anniversaire de la semaine sanglante. L'Intransigeant, 30 May 1882.

L'Intransigeant. 1883a. L'anniversaire de la semaine sanglante. L'Intransigeant, 29 May 1883. 
L'Intransigeant. 1883b. 'L'inauguration du monument de la défense de Paris,

L'Intransigeant, 14 August 1883.

Le Monde Illustré, 4 November 1871.

Le Monde Illustré, 9 December 1871.

Le Petit Journal, 1 July 1871.

Le Petit Journal, 25 May 1880.

Le Petit Journal, 30 May 1880.

Le Petit Journal. 1872a. Les anniversaires Montretout-Buzenval. Le Petit Journal, 21

January 1872 .

Le Petit Journal. 1872b. Les anniversaires. Le Petit Journal, 30 May 1872.

Le Petit Journal. 1872c. Les anniversaires, Le Petit Journal, 31 May 1872.

Le Siècle, 21 January 1872.

Le Siècle, 23 May 1880.

Le Siècle, 24 May 1880.

Le Temps, 1 July 1871.

Le Temps, 26 May 1880.

MacMahon, P. 1872. L'Armée de Versailles depuis sa création jusqu'à la complète pacification de Paris. Paris: A. Ghio.

Marx, K. 1871. The Civil War in France: An Address of the General Council of the International Working Men's Association. London: Edward Truelove.

Merriman, J. M. 2014. Massacre: The Life and Death of the Paris Commune of 1871. New Haven: Yale University Press.

Milner, J. 2000. Art, War and Revolution in France 1870-1871: Myth, Reportage and Reality. New Haven: Yale University Press.

Montancey, L. 1880. L'anniversaire du 18 mars. Le Figaro, 18 March 1880. 
Nicholls, J. 2019. Revolutionary Thought after the Paris Commune, 1871-1885.

Cambridge: Cambridge University Press.

Nietzsche, F. 1956. The Birth of Tragedy and The Genealogy of Morals (first published 1887). New York: Anchor Books.

Nora, P. 1996. Conflicts and Divisions. In: P. Nora ed. Realms of Memory, vol. 1. New York: Columbia University Press, pp. 21-25.

O’Squarr, F. 1871. L’anniversaire du Bourget. Le Figaro, 1 November 1871.

Paris-Journal. 1872a. Le 19 janvier. Paris-Journal, 21 January 1872.

Paris-Journal. 1872b. Messes Expiatoires. Paris-Journal, 30 May 1872.

Rebérioux, M. 1984. Le mur des fédérés: rouge 'sang craché'. In: P. Nora, ed. Les lieux de mémoire, Vol. 1. Paris: Gallimard, pp. 619-49.

Ricoeur, P. 2004. Memory, History, Forgetting. Chicago: University of Chicago Press.

Rousset, L. 1912. Histoire générale de la guerre franco-allemande (1870-1871), Vol. 3.

Paris: Librairie Illustrée.

Runia, E. 2006. Spots of Time. History and Theory, 45(3), 305-16.

Séguin, L. 1879. Le ministère de la Guerre sous la Commune. Paris: Chelu.

Shafer, D. A. 2005. The Paris Commune. London: Palgrave.

Talmeyr, M. 1883. Souvenirs du siège. L'Intransigeant, 14 August 1883.

Tartakowsky, D. 1999. Nous irons chanter sur vos tombes: Le Père Lachaise, XIXe-XXe siècle. Paris: Aubier.

Tillier, B. 2004. La Commune de Paris, révolution sans image? Politique et représentations dans la France républicaine (1871-1914). Paris: Champ Vallon.

The Times, 1 July 1871

The Times, 3 July 1871. 
Thomas, J. 1879. Concours pour l'érection au rond-point de Courbevoie d'un monument allégorique de la défense de Paris en 1870. Rapport au nom du jury chargé du classement des esquisses. Paris: A. Chaix et Cie.

Tombs, R. 1981. The War Against Paris 1871. Cambridge: Cambridge University Press. Tombs, R. 1986. Paris and the Rural Hordes: An Exploration of Myth and Reality in the French Civil War of 1871. The Historical Journal, 29(4), 795-808.

Tombs, R. 1994. Victimes et bourreaux de la Semaine sanglante. 1848. Révolutions et mutations au XIXe siècle, 10, 81-96.

Tombs, R. 1999. The Paris Commune1871. London: Longman.

Tombs, R. 2012. How Bloody was la Semaine Sanglante of 1871? A Revision. The Historical Journal, 55(3), 679-704

Truesdell, M. N. 1997. Spectacular Politics: Louis-Napoleon Bonaparte and the Fête Impérial, 1849-1870. New York, Oxford University Press.

Varley, K. 2008. Under the Shadow of Defeat: The War of 1870-71 in French Memory. Basingstoke: Palgrave.

White, H. 1975. Metahistory: The Historical Imagination in Nineteenth-Century Europe. Baltimore: John Hopkins University Press.

Wilson, C. 2007. Paris and the Commune 1871-78: The Politics of Forgetting. Manchester: Manchester University Press.

Winter, J. and Sivan, E. 1999. Setting the Framework. In: J. Winter and E. Sivan eds. War and Remembrance in the Twentieth Century. Cambridge: Cambridge University Press.

Winter, J. 2010. Thinking about Silence. In: E. Ben-Ze'ev, R. Ginio and J. Winter, eds. Shadows of War: A Social History of Silence in the Twentieth Century. Cambridge:

Cambridge University Press, 3-31. 
Zerubavel, E. 2010. The Social Sound of Silence: Toward a Sociology of Denial. In: E. Ben-Ze'ev, R. Ginio and J. Winter, eds. Shadows of War: A Social History of Silence in the Twentieth Century. Cambridge: Cambridge University Press, 32-44. 